\title{
Mathematical Modeling of Drying Pattern of Ogi Produced From Two Types of Maize Grain
}

\author{
Bolaji O. T. ${ }^{1}$, Olalusi A. P. ${ }^{2} \&$ Adesina B. S. ${ }^{3}$ \\ ${ }^{1}$ Department of Food Technology, Lagos State Polytechnic, Ikorodu, Lagos, Nigeria \\ ${ }^{2}$ Department of Agricultural and Environmental Engineering Federal University of Technology, Akure, Nigeria \\ ${ }^{3}$ Department of Agricultural and Environmental Enginering, Lagos State Polytechnic, Ikorodu, Nigeria \\ Correspondence: Bolaji O. T., Department of Food Technology, Lagos State Polytechnic, Ikorodu, Lagos, \\ Nigeria. Tel: 234-802-972-0909. E-mail: olusholat@yahoo.com
}

Received: August 14, 2014 Accepted: October 27, 2014 Online Published: December 29, 2014

doi:10.5539/jfr.v4n1p174 URL: http://dx.doi.org/10.5539/jfr.v4n1p174

\begin{abstract}
This paper presents thin layer modeling of ogi produced from yellow and white maize at varying soaking period and dried in the cabinet and oven at $50{ }^{\circ} \mathrm{C}$. The moisture decrease for cabinet dried ogi produced from white maize from $49.011 .5 \%, 49.5$ to $11.32 \%, 46.5$ to $12.33 \%$ and $46.12 .29 \%$. The drying rate for both oven and cabinet dried ogi produced from yellow maize decreased from 4.6 to $0.0525 \mathrm{~kg} / \mathrm{min}, 4.5$ to $0.0513 \mathrm{~kg} / \mathrm{min}, 4.35$ to $0.049 \mathrm{~kg} / \mathrm{min}$ and 4.4 to $0.047 \mathrm{~kg} / \mathrm{min}$ while for oven dried ogi followed a similar trend. The experimental data obtained were fitted to five thin layer models: Newton, Page, Herderson and Pabis, Two term and Wingh and Singh models. The values obtained for ogi produced from white maize and dried in the cabinet and oven at $50{ }^{\circ} \mathrm{C}$ for Newton model gave a lower $\mathrm{R}^{2}, \chi^{2}$, RMSE compared with respective values obtained from Page, Herderson and Pabis, two term, Wing and Singh models. The two terms model appear to be the best model among the five models used in this work and had higher $\mathrm{R}^{2}$, lower $\chi^{2}$, and RMSE. The ogi produced from yellow maize at varying soaking period of $24,48,72$ and 96 hours and dried in cabinet dryer and fitted with two term showed model constants $\mathrm{a}, \mathrm{K}_{0}, \mathrm{~b}, \mathrm{~K}_{1} 0.04315,0.0388995,0.919,2.2 \times 10^{-3}$ while the $\mathrm{R}^{2}, \chi^{2}$ RMSE were $0.9933,5.85 \times$ $10^{-4}$ and $4.85 \times 10^{5}$ for ogi produced for 24 hours soaking, respectively. The soaking period does not seem to affect the moisture ratio and the thin layer drying model. However, the initial moisture and equipment seems to affect significantly.
\end{abstract}

Keywords: modeling, drying, ogi slurry, thin layer, maize

\section{Introduction}

Dehydration is one of the oldest methods of food preservation and may be complicated process that involves simultaneous heat and mass transfer (Sarsavadia et al., 1999; Maskan et al., 2002; Shi et al., 2008). In this process, water is transferred by diffusion from interior part of the food material to outer surface and subsequently evaporated (Maskan et al., 2002; Sahin \& Dincer, 2005; Hawlader et al., 2006). It is an important food processing condition aimed at producing a high-density product which when adequately packaged should prolong the shelf-life and be rapidly reconstituted without significant loss in quality charateristics (Sarsavadia et al., 1999; Lima et al., 2002; Maskan et al., 2002; Moraga et al., 2004; Maskan, 2001; Alves-Filho, 2002; Hawlader et al., 2006; Shi et al., 2008).

Drying process can be described using an appropriate drying models require adequate application of knowledge of material transport and properties (Karathanos, 1999; Alves-Filho, 2002; Shi et al., 2008). The common relevant properties useful in the application are moisture diffusivity, thermal conductivity, density, specific heat capacity; inter phase heat and mass transfer coefficients (Karathanos, 1999; Hernandez et al., 2000; Alves-Filho, 2002; Shi et al., 2008). Among many mathematical models, thin layer drying models have found wide application due to their ease of use. Time of application and assumptions of geometry of a typical food is always needed for computation (Madamba et al., 1996; Kingsly et al., 2007). Among semi theoretical thin layer drying models, the Newton model, Page model, the modified Page model (I and II), the Henderson and Pabis model, the logarithmic model, the two term model, the two-term exponential, the diffusion approach model have been used by many researchers (Lima et al., 2002; Maskan et al., 2002; Moraga et al., 2004; Maskan, 2001; Alves-Filho, 
2002; Hawlader et al., 2006; Shi et al., 2008). Empirical models derive a direct relationship between average moisture content and drying time (Karathanos, 1999; Hernandez et al., 2000; Alves-Filho, 2002; Shi et al., 2008; Madamba et al., 1996; Kingsly et al., 2007). Drying kinetics is generally evaluated experimentally by measuring the weight of a drying sample as a function of time (Midilli, 2001; S. Erenturk \& K. Erenturk, 2007; Khazaei et al., 2008). It has been established that Drying kinetics is greatly affected by air temperature, air velocity, material size, drying time (S. Erenturk \& K. Erenturk, 2007; Khazaei et al., 2008).

Some of the thin layer models reported in literature were for drying of Toria seeds (Rangroo \& Rao, 1992), Dates (Bakri \& Hobani, 2000), chili pepper (Toyosi \& Adeladun, 2010), varieties millet samples (Ojendiran \& Raji, 2010), Srilankan paddy (Syamali et al., 2009), Sesame seeds (Khazaei \& Daneshmandi, 2007), Amaranth grain (Ronoh et al., 2010), hazelnut (Ozdemir \& Devres, 1999), green pepper, green bean and squash (Yaldiz \& Ertekin, 2001), apricot (Togrul \& Pehlivan, 2003; Sarsilmaz et al., 2000), green chilli (Hossain \& Bala, 2002), pistachio (Midilli \& Kucuk, 2003), apple (Sacilik \& Elicin, 2005), pumpkin (Akpinar et al., 2003b), red pepper (Akpinar et al., 2003a), eggplant (Ertekin \& Yaldiz, 2004), bay leaves (Gunhan et al., 2005), rosehip (Erenturk et al., 2004) and strawberries (Alvarez et al., 1995).

Ogi produced from maize is the product obtained by fermentation of corn (Akingbala et al., 1981; Bolaji et al., 2011). The softened corn is washed and wet milled, sieved and sedement (Banigo \& Muller, 1972). There has not been any substantial difference between the traditional and commercial manufacturing of ogi. Some modification have been introduced such as dry milling of maize into a fine flour and subsequent inoculation of the flour water mixture with a culture of lactobacilli and yeast this is still not in general practice compared with the traditional method (Akingbala et al., 1981). According to Maskan 2001, the use high quality dried foods with good rehydration properties has become an interesting alternative to chemicals preservatives in food. This can be applied to ogi which is widely consumed within the geographical segments of Nigeria.

In view of the importance of ogi in the Nigerian diet, large scale production is appearing indispensable. The ogi material could be dried and package in polythene bags for an increased shelf life. There are many different types and variation of dryers, and selecting the proper dryer is crucial to achieving the desired results. Different types of dryers may be necessary depending on capacity, product quality, size, consistency, hours of operation, quantity of water to be evaporated, acidity of the product, operational environment and volatility of its flavor (S. Erenturk \& K. Erenturk, 2007; Khazaei et al., 2008; Midilli, 2001). In addition, the nature of contact with food material, source of energy and the nature of the food material.

In most cases of application of thin layer drying, a finer grain obtained as result of millied process is rarely considered. Past work has been limited to vegetables, fruits, grains (legumes, cereals, seeds which particle size are quite larger compared with the particle size of fine ogi. Also, literature is very scanty on the application of thin layer to finely- grind product made through a sieve meshes ( 0.6 micron and below)-fine grains like ogi slurry obtained from fermented, milled, sieved, sedimented slurry consumed as weaning food and adult gruel. This work is attempted to find out if some common thin layer drying models may be relevant in describing the drying behavior of ogi. This may be subsequently useful in predicting, designing or selecting appropriate drying process and equipment for this product.

\section{Method}

Maize used for this experiment was obtained from a local market at Ketu, Lagos, Nigeria. Four kilogram were divided into four and each $(1 \mathrm{~kg})$ of the maize was weighed into bowl after thorough cleaning. Water was added and soaked for 24, 48, 72 and 96 hours. The soaked maize at different period was wet milled and were sieved with muslin clothe. The sediment was put in Muslim cloth and squeezed to drain the water ready for drying in two different dryer (cabinet and hot air oven) at $50^{\circ} \mathrm{C}$. The ogi paste was spread to form a uniform thickness in the dryer stray $(10 \mathrm{~mm})$. This selection was necessary considering the gelatinization temperature of most starches and ogi (Bolaji et al., 2011). The moisture contents of paste were monitored at an interval of 10 minutes for 240 minutes (4 hours) subsequently at an interval of 2 hours for additional 4 hours.

\subsection{Moisture Determination}

The method of A.O.A.C (1990) was used to determine the moisture content of the ogi paste. A known mass of the paste was placed in an oven at $110^{\circ} \mathrm{C}$ for 3 hours, weighing was done. The final weight was taken when the product had cooled down inside a desiccator and the moisture content determined as a ratio of weight of water to weight of wet paste expressed in \% as shown in Equation (1).

$$
\text { Moisture contnent }(\%)=\frac{\text { weight of sample-weight after drying }}{\text { weight of sample }} \times 100
$$




\subsection{Thin Layer Models}

Drying kinetics models employed in this work are as shown in Table 1. The drying constant and coeffiecints of the models were determined by non-linear regression analysis. Among the models tested to interpret the drying behavior of ogi slurry was Lewis model used to describe the drying of barley (Bruce, 1985) while page model is an empirical modification of Lewis model to overcome some of its shortcomings. It has been successfully used to describe the drying characteristics of some agricultural products (Menges \& Ertekin, 2006).Wang and Singh model is a second order polynomial model, which has earlier been used to characterize the drying kinetics of rough rice (Wang \& Singh, 1978). The two-term model is the first two terms of general series solution of Fick's second law regardless. According to Sacilik and Unal (2005) reported that it requires constant product temperatures during drying and assumes that diffusivity is constant. In this proposed models a, $b, c$ and $n$ are the drying coefficients and $k$ is the drying constant $\left(\mathrm{min}^{-1}\right)$.

Table 1. Some thin layer models

\begin{tabular}{cccc}
\hline s/no & Model name & Model equation & References \\
\hline 1 & Newton & $M R=\exp (-k t)$ & Bruce, 1985 \\
2 & Page & $M R=\exp (-k t)^{n}$ & Page 1949 \\
3 & Herderson and Pabis & $M R=a \cdot \exp (-k t)$ & Herderson and Pabis(1961) \\
4 & Two term model & $M R=a \cdot \exp \left(-k_{0} t\right)+b \cdot \exp \left(-k_{1} t\right)$ & Herderson and Pabis(1974) \\
5 & Wang ang Singh & $M R=1+a t+b t^{2}$ & Wang and Sing (1978) \\
\hline
\end{tabular}

\subsection{Mathematical Modeling}

According to Midilli (2001), Drying characteristics can be investigated by effectively modeling the drying behavior. Drying experiments were expressed in dimensionless form as moisture ratios MR with the following equation)

$$
M R=\frac{M-M_{e}}{M_{i}-M_{e}}=\exp (-k t)
$$

where $M$ is the moisture content at any time, $M_{i}$ is the initial moisture content and $M_{e}$ is the equilibrium moisture content. The values of $M_{e}$ may be relatively small compared to $M$ and $M_{i}$, so the equation can be simplified to $M R=M / M_{i}$ (Thakor et al., 1999; Akgun \& Doymaz, 2005; Togrul \& Pehlivan, 2002). The non linear regression analysis in the present study was performed using the OriginPro 8. The goodness of fit of the tested mathematical models to the experimental data was evaluated with the correlation coefficient $\left(\mathrm{R}^{2}\right)$, the reduced chi square $\left(\chi^{2}\right)$ and the root mean square error $(R M S E)$. The higher the values of the $\mathrm{R}^{2}$, and lowest values of the $\chi^{2}$ and RMSE, the better the goodness of the fit (Yaldiz \& Ertekin, 2001; Akpinar et al., 2003; Gunhan et al., 2005; Doymaz et al., 2004; Sacilik \& Elicin, 2005). The $\chi^{2}$ and RMSE were evaluated as as showin in Equations (2) and (3)

$$
\begin{gathered}
R M S E=\left[\frac{1}{N} \sum_{I=1}^{N}\left(M R_{\text {pred }, i}-M R_{\text {exp }}\right)^{2}\right]^{1 / 2} \\
\chi^{2}=\frac{\sum_{\mathrm{i}=1}^{\mathrm{n}}\left(\mathrm{MR}_{\text {exp }, \mathrm{i}}-\mathrm{MR}_{\text {pre }, \mathrm{i}}\right)^{2}}{\mathrm{~N}-\mathrm{n}}
\end{gathered}
$$

Where $\mathrm{MR}_{\text {pre }}$ is predicted moisture ratio and $\mathrm{MR}_{\text {exp }}$ is experimental moistre ratio.

\section{Results}

The moisture decreased for cabinet dried ogi produced from white maize from 49.0 to $11.5 \%, 49.5$ to $11.32 \%$, 46.5 to $12.33 \%$ and 46.0 to $12.29 \%$ respecitively. While the moisture cotent for oven dried ogi produced from white maize decreased from 49.0 to $12.6 \%, 49.5$ to $12.32 \%, 46.5$ to $11.99 \%$ and 45.0 to $11.31 \%$, rescpectively. 
The moisture ratio in Figure 1 showed that moisture in ogi samples decreased continually with drying time.

Cabinet dried Ogi produced from White maize

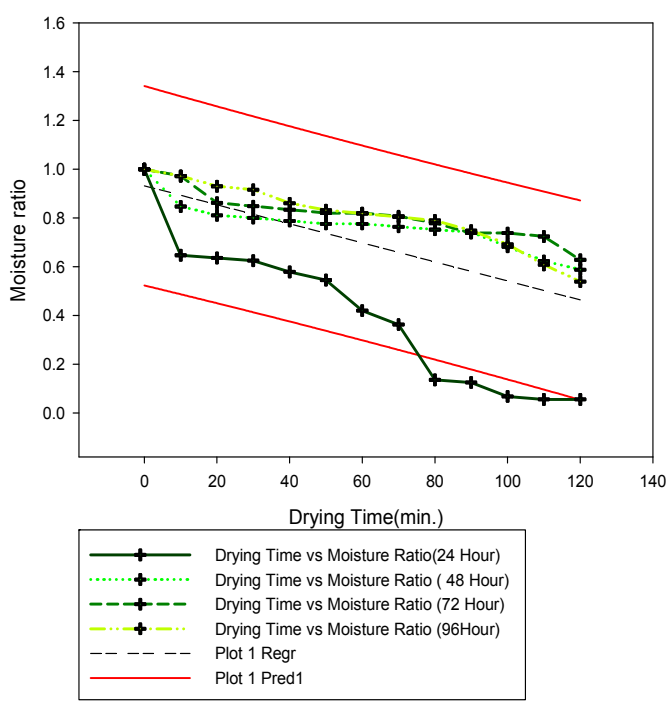

Oven dried Ogi produced from yellow maize
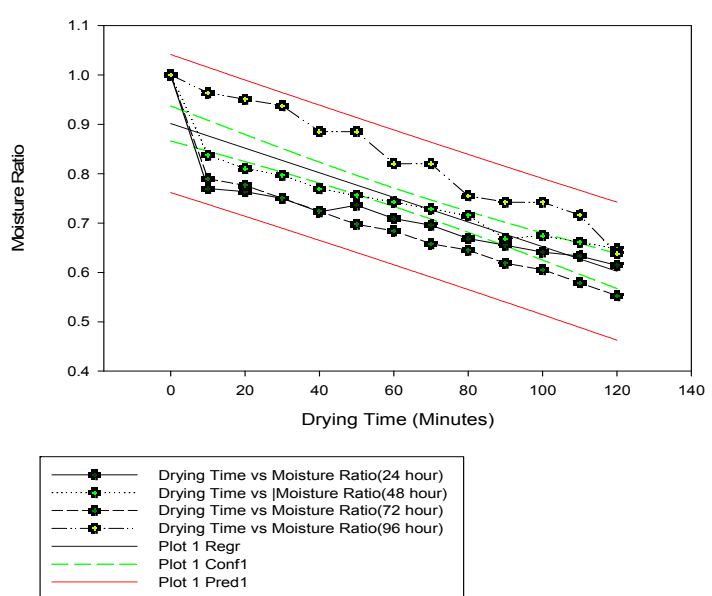

Oven dried Ogi produced from white maize
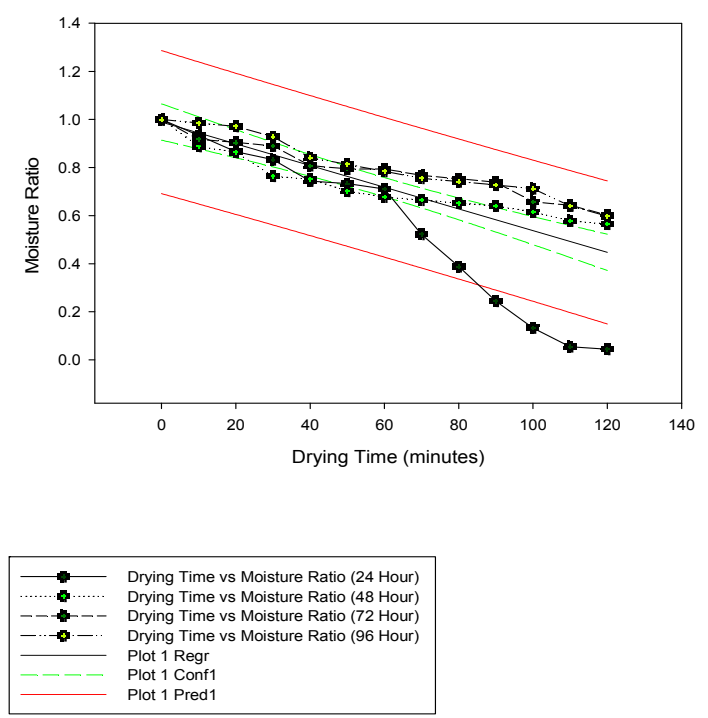

Cabinet dried Ogi produced from yellow maize

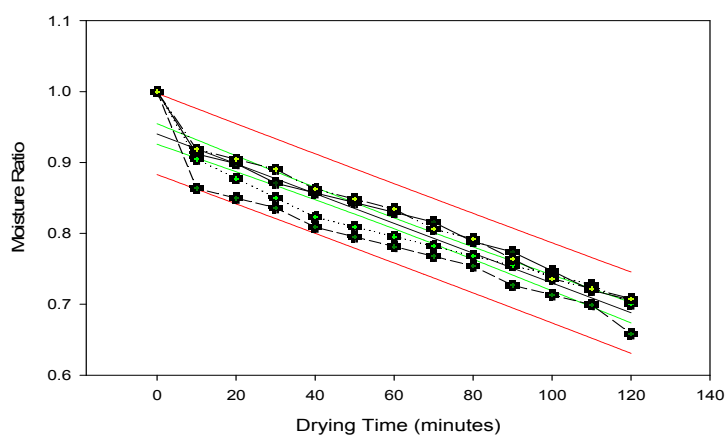

Drying Time vs Moisture Ratio(24 Hour) Drying Time vs Mooisture Ratio(48 Hour) Drying Time vs Moisture Ratio(72 Hour) Drying Time vs Moisture Ratio(96 Hour) Plot 1 Conf 1 Plot 1 Conf 1
Plot 1 Pred1

Figure 1. Moisture ratio relationship with drying time

The drying rate for both oven and cabinet dried ogi produced from yellow maize decreased from 4.6 to 0.0525 , 4.5 to $0.0513,4.35$ to 0.049 and 4.4 to $0.047 \mathrm{~kg} / \mathrm{min}$. While the drying rate in cabinet dried $O g i$ decreased from 4.8 to $0.37,4.7$ to $0.36,4.5$ to 0.35 and 4.55 to $0.35 \mathrm{~kg} / \mathrm{min}$. The drying rate recorded for oven and cabinet dried ogi porudced from white maize also ranged from 3.35 to $0.02083,4.3$ to $0.047,4.55$ to 0.051 and 4.5 to 0.05 $\mathrm{kg} / \mathrm{min}$.

The statiscal parameters of five common drying models used and fitted with $R M S E$ and $\chi^{2}$ used to evaluate the best model were presented in Tables $2,3,4,5$ and 6 . The drying constant k, obtained for Newton model for ogi produced from maize soaked for 24 hours and dried in a cabinet dryer were $3.06 \times 10^{-3}$ with $\mathrm{R}^{2}$ of $0.8963, \chi^{2}$ of $0.7071 \times 10^{-4}$ and $R M S E$ of 0.021 . Also for ogi produced from maize soaked at 48 hours and dried in the cabinet at $50{ }^{\circ} \mathrm{C}$, k is $3.35 \times 10^{-3}$ with $\mathrm{R}^{2}$ of $0.77773, \chi^{2}$ of $1.5 \times 10^{-3}, R M S E$ of 0.26 . Ogi produced from maize Maize soaked for 72 and 96 hours of soaking followed similar trend as shown in Table 2. The result for Oven dried Ogi from yellow maize at $50{ }^{\circ} \mathrm{C}$ and 24 hours soaking time, revealed a k value to be $3.06 \times 10^{-3}, \mathrm{R}^{2}$ is $0.795, \chi^{2}$ is $3.167 \times 10^{-3}, R M S E$ is 0.054 ; and $\mathrm{k}$, at 48 hours soaking time, is $4.45 \times 10^{-3}$ with $\mathrm{R}^{2}$ of $0.882, \chi^{2}$ of $2.28 \times 10^{-3}$, RMSE of 0.044 for ogi produced from yellow maize. The values obtained for ogi produced from white maize 
and dried in the cabinet and oven at $50{ }^{\circ} \mathrm{C}$, respectively revealed a similar trend. The $\mathrm{R}^{2}$ were lower, compared with respective values obtained in page, Herderson and Pabis, Wang ang Singh models and two term models. The $\chi^{2}$ and RMSE were contrary, their values were higher.

Table 2. Newton models constants and statistical parameters

\begin{tabular}{|c|c|c|c|c|}
\hline & $\mathrm{k}\left(\times 10^{-3}\right)$ & $\mathrm{R}^{2}$ & $\operatorname{RMSE}\left(\times 10^{-1}\right)$ & $\chi^{2}\left(\times 10^{-3}\right)$ \\
\hline \multicolumn{5}{|c|}{ Cabinet dreid Ogi Produced from Yellow Maize } \\
\hline & 3.06 & 0.89683 & 2.1 & 0.707 \\
\hline & 3.35 & 0.77773 & 2.6 & 1.5 \\
\hline & 3.76 & 0.71574 & 3.5 & 2.5 \\
\hline & 3.07 & 0.93906 & 5.81 & 4.53 \\
\hline Mean & 3.31 & 0.83234 & 3.55 & 1.215 \\
\hline \multicolumn{5}{|c|}{ Oven dried Ogi produced from Yellow Maize } \\
\hline & 3.06 & 0.795 & 5.4 & 3.167 \\
\hline & 4.45 & 0.882 & 4.4 & 2.25 \\
\hline & 5.81 & 0.904 & 4.8 & 1.0 \\
\hline & 3.19 & 0.964 & 2.8 & 3.583 \\
\hline Mean & 4.13 & 0.88625 & 3.14 & 2.5 \\
\hline \multicolumn{5}{|c|}{ Cabinet dried Ogi produced from White Maize } \\
\hline & 3.03 & 0.89683 & 7.0 & 0.706 \\
\hline & 3.05 & 0.77773 & 0.9 & 1.6. \\
\hline & 3.67 & 0.71574 & 3.2 & 2.4 \\
\hline & 3.107 & 0.93906 & 1.6 & 5.53 \\
\hline Mean & 3.30 & 0.83234 & 3.18 & 13.15 \\
\hline \multicolumn{5}{|c|}{ Oven dried Ogi produced from Yellow Maize } \\
\hline & 18.2 & 0.89151 & 5.7 & 9.71 \\
\hline & 4.27 & 0.67199 & 2.6 & 3.42 \\
\hline & 3.43 & 0.87952 & 2.8 & 1.19 \\
\hline & 3.82 & 0.91815 & 2.5 & 1.52 \\
\hline Mean & 7.43 & 0.840293 & 3.4 & 3.96 \\
\hline
\end{tabular}

However, the Two term odel appears to be the best model among the five models used in this work with higher $\mathrm{R}^{2}$, and lower $\chi^{2}$, and RMSE. The ogi produced from yellow maize at varying soaking period of 24 hours and dried with cabinet dryer and fitted with two terms is as shown in Table 5. The result revealed constants $\mathrm{a}, \mathrm{K}_{0}, \mathrm{~b}$, $\mathrm{K}_{1}$ were $0.00594,0.0202,0.941,0.00228$, and $\mathrm{R}^{2}$, was $0.9901, \chi^{2}, 7.84 \times 10^{-4}, R M S E, 8.22 \times 10^{-5}$, respectively.

The values for ogi produced from 48 hours were $0.0103,0.0125,0.891,0.00195$ while the $\mathrm{R}^{2}, \chi^{2}$ and, RMSE were $0.996823,2.57 \times 10^{-4}$ and $2.85 \times 10^{-5}$, respectively. Ogi produced from white maize and dried at the oven follow a similar trend. The $\mathrm{R}^{2}, \chi^{2}$ and $R M S E$ obtained for all the models for ogi produced from white maize and dried in the cabinet at the temperature used in this research work were lower as revealed by Newton, Page, Herdeson and Pabis and Two term models. The values of $\mathrm{R}^{2}$ and other statistical parameters were lower compared to the findings of several previous works in fitting the model to the experimental data and only the values obtained from Two term model falls within range obtained for drying of apple $\left(\mathrm{R}^{2}=0.99869, \chi^{2}=2.68 \times 10^{-4}\right)$ and pumpkin $\left(\mathrm{R}^{2}=0.98952\right.$ and $\left.\chi^{2}=2.31 \times 10-3\right)$ as reported by Akpinar $(2006)$; green table olives $\left(\mathrm{R}^{2}=0.9890\right.$ to 0.9987, RMSE $=0.009341$ to 0.025469 , and $\chi^{2}=8.9 \times 10^{-5}$ to $6.54 \times 10^{-4}$ ) as reported by Demir et al. (2007); drying of figs $\left(\mathrm{R}^{2}=0.9912, \chi^{2}=7.06 \times 10^{-3}\right.$, and $\left.R M S E=0.074918\right)$ as reported by Doymaz (2005); black grapes $\left(\mathrm{R}^{2}=\left(0.9794\right.\right.$ to $0.9989, \chi 2=1.01 \times 10^{-4}$ to $\left.1.772 \times 10^{-3}\right)$ as reported by Doymaz (2006); prickly pear fruit $\left(\mathrm{R}^{2}=\right.$ 
0.9993 and $\left.\chi^{2}=1.1457 \times 10^{-4}\right)$, drying shelled pistachios $\left(\mathrm{R}^{2}=0.9668, \chi^{2}=4.756 \times 10^{-4}\right)$ and unshelled $\left(\mathrm{R}^{2}=0.970\right.$ and $\left.\chi^{2}=4.737 \times 10^{-4}\right)$; natural solar drying of shelled pistachios $\left(\mathrm{R}^{2}=0.9380, \chi^{2}=4.521 \times 10^{-4}\right)$ and unshelled pistachios $\left(\mathrm{R}^{2}=0.9750\right.$ and $\left.\chi^{2}=3.360 \times 10^{-4}\right)$, according to Midilli and Kucuk (2003); drying of single apricot: $\left(\mathrm{R}^{2}=0.990, R M S E=0.0487\right.$ and $\left.\chi^{2}=0.002395\right)$ by Togrul and Pehlivan (2003); solar drying of sultana grapes: $\left(\mathrm{R}^{2}=0.973\right.$ and $\left.\chi^{2}=0.005\right)$ as reported by Yaldiz et al. $(2001)$.

Table 3. Page models constants and statistical parameters

\begin{tabular}{|c|c|c|c|c|c|}
\hline & $\mathrm{k}$ & $\mathrm{n}$ & $\mathrm{R}^{2}$ & $R M S E\left(\times 10^{-2}\right)$ & $\chi^{2}\left(\times 10^{-3}\right)$ \\
\hline \multicolumn{6}{|c|}{ Cabinet Oven dried ogi produced from Yellow Maize } \\
\hline & 1.3399 & 0.548 & 0.945 & 5.4 & 1.833 \\
\hline & 1.2499 & 0.497 & 0.992 & 3.9 & 2.75 \\
\hline & 1.10889 & 0.415 & 0.925 & 3.9 & 4.0 \\
\hline & 1.404 & 0.605 & 0.945 & 5.6 & 1.417 \\
\hline Mean & 1.275673 & 0.516 & 0.95175 & 4.7 & 2.5 \\
\hline \multicolumn{6}{|c|}{ Oven dried ogi produced from yellow maize } \\
\hline & 0.732 & 0.264 & 0.87 & 3.5 & 3.292 \\
\hline & 0.9861 & 0.373 & 0.954 & 6.1 & 1.917 \\
\hline & 0.905 & 0.383 & 0.937 & 2.9 & 3.708 \\
\hline & 1.79092 & 1.047 & 0.957 & 1.9 & 1.083 \\
\hline Mean & 1.103505 & 0.51675 & 0.9295 & 7.875 & 2.5 \\
\hline \multicolumn{6}{|c|}{ Cabinet dried ogi produced from White Maize } \\
\hline & 1.2615 & 0.909 & 0.777 & 1.87 & 4.0 \\
\hline & 1.0349 & 0.391 & 0.777 & 3.14 & 2.75 \\
\hline & 1.604827 & 0.851 & 0.851 & 2.62 & 1.625 \\
\hline & 1.81482 & 1.123 & 0.968 & 2.87 & 1.625 \\
\hline Mean & 1.429012 & 0.8185 & 0.84325 & 2.625 & 2.5 \\
\hline \multicolumn{6}{|c|}{ Oven dried ogi produced from White Maize } \\
\hline & 1.909394 & 1.553 & 0.896 & 2.23 & 3.5 \\
\hline & 1.293 & 0.645 & 0.97 & 2.1 & 3.417 \\
\hline & 1.475678 & 0.734 & 0.928 & 2.26 & 1.583 \\
\hline & 1.9796 & 1.4332 & 0.962 & 4.45 & 1.5 \\
\hline & Mean & 1.664418 & 1.0913 & 9.39 & 1.96 \\
\hline
\end{tabular}

The study showed that drying ogi smaples in the cabinet dryer and hot air oven showed decrease in moisture content with increased drying at the same temperature of $50{ }^{\circ} \mathrm{C}$ for 240 minutes. Drying of ogi may be achieved within the drying time employed in this research work however this is dependent on the quantity. Soaking period however did not reveal a significant effect on the drying pattern of ogi.The two term model showed a best model fit with Higher $\mathrm{R}^{2}$, lower $\chi^{2}$ and $R M S E$ followed by the Wang and Singh model. The values for $\mathrm{R}^{2}, \chi^{2}$ and $R M S E$ were highest in cabinet and oven dried ogi produced from yellow maize in all the models compared with the white ogi produced from white maize. 
Table 4. Herderson and Pabis models constants and statistical parameters

\begin{tabular}{|c|c|c|c|c|c|}
\hline & $\mathrm{A}$ & $\mathrm{k}$ & $\mathrm{R}^{2}$ & $R M S E\left(\times 10^{-3}\right)$ & $\chi^{2}\left(\times 10^{-4}\right)$ \\
\hline \multicolumn{6}{|c|}{ Cabinet dried ogi produced from Yellow Maize } \\
\hline & 0.95899 & -0.00252 & 0.95784 & 9 & 2.89 \\
\hline & 0.93839 & -0.00252 & 0.91691 & 8 & 5.59 \\
\hline & 0.92475 & -0.00274 & 0.89432 & 14 & 8.17 \\
\hline & 0.96746 & -0.00264 & 0.97435 & 9 & 1.91 \\
\hline \multirow[t]{6}{*}{ Mean } & 0.947398 & -0.00261 & 0.935855 & 10 & 4.64 \\
\hline & Oven dri & duced fror & ow Maize & & \\
\hline & 0.86077 & -0.00309 & 0.72608 & 13 & 26.6 \\
\hline & 0.8993 & -0.00304 & 0.84305 & 13 & 1.42 \\
\hline & 0.88114 & -0.00407 & 0.85675 & 9 & 1.96 \\
\hline & 1.01414 & -0.00337 & 0.96576 & 28 & 4.27 \\
\hline \multirow[t]{6}{*}{ Mean } & 0.913838 & -0.00339 & 0.84791 & 15.75 & 1.617 \\
\hline & Cabinet & produced f & Vhite Maiz & & \\
\hline & 0.88527 & -0.01738 & 0.95714 & 33.58 & 10.27 \\
\hline & 0.82248 & -0.00314 & 0.91741 & 14.41 & 1.85 \\
\hline & 0.89849 & -0.003 & 0.96752 & 9.37 & 1.01 \\
\hline & 0.91879 & -0.00412 & 1.02328 & 5.04 & 1.51 \\
\hline \multirow[t]{6}{*}{ Mean } & 0.881258 & -0.00691 & 0.966338 & 15.6 & 3.66 \\
\hline & Oven dri & duced froı & ite Maize & & \\
\hline & 0.95714 & -0.01738 & 0.88527 & 10.27 & 11.27 \\
\hline & 0.91741 & -0.00314 & 0.82248 & 18.0 & 1.85 \\
\hline & 0.96752 & -0.003 & 0.89849 & 1.02 & 3.01 \\
\hline & 1.02328 & -0.00412 & 0.91879 & 2.01 & 1.51 \\
\hline Mean & 0.966338 & -0.00691 & 0.881258 & 7.825 & 4.816 \\
\hline
\end{tabular}

The drying process was affected substantially by the consistent changing temperature gradient most expecailly at the at the beginignof the experiment. This was consistent with several researchers report (Akendo et al., 2008; Belghit et al., 2000; Falade \& Abbo, 2007; Methakhup et al., 2005) of free water present at the start is vary, the rate of water removal is always higher during this at this stage(Guine' et al., 2007). As the drying proceeds, the free water presents decreases quite rapidly, until the final stages when water was hardly available and the drying becomes very slow. This was reflected in the drying rate. 
Table 5. Two term models constants and statistical parameters

\begin{tabular}{|c|c|c|c|c|c|c|c|}
\hline & $\mathrm{a}$ & $\mathrm{k}_{0}$ & $\mathrm{~b}$ & $\mathrm{k}_{1}$ & $\mathrm{R}^{2}$ & $R S M E\left(\times 10^{-5}\right)$ & $\chi^{2}\left(\times 10^{-4}\right)$ \\
\hline \multicolumn{8}{|c|}{ Cabinet dried ogi produced from Yellow Maize } \\
\hline & 0.00594 & 0.0202 & 0.941 & 0.00228 & 0.9901 & 8.22 & 7.84 \\
\hline & 0.0103 & 0.0125 & 0.891 & 0.00195 & 0.996823 & 2.85 & 2.57 \\
\hline & 0.109 & 0.000898 & 0.891 & 0.00226 & 0.99234 & 8.18 & 7.36 \\
\hline & 0.0473 & 0.122 & 0.953 & 0.00245 & 0.993778 & 0.163 & 5.65 \\
\hline Mean & 0.043135 & 0.0388995 & 0.919 & 0.002235 & 0.99326 & 4.852 & 5.85 \\
\hline \multicolumn{8}{|c|}{ Oven dried ogi produced from Yellow Maize } \\
\hline & 0.204 & 0.00141 & 0.797 & 0.0021 & 0.993362 & 8.60 & 7.73 \\
\hline & 0.15 & 0.39 & 0.85 & 0.00231 & 0.993839 & 7.43 & 6.68 \\
\hline & 0.178 & 0.0000145 & 0.822 & 0.00317 & 0.998202 & 3.28 & 2.98 \\
\hline & 0.464 & 0.00337 & 0.55 & 0.0 .337 & 0.968614 & 50.0 & 4.7 \\
\hline Mean & 0.249 & 0.0986986 & 0.75475 & 0.002527 & 0.988504 & 17.3243 & 5.52 \\
\hline \multicolumn{8}{|c|}{ Cabinet dried ogi produced from White Maize } \\
\hline & 0.482 & 0.0174 & 0.475 & 0.0172 & 0.894828 & 1.26 & 1.1294 \\
\hline & 0.31 & 0.00314 & 0.607 & 0.00314 & 0.837271 & 2.3 & 2.0372 \\
\hline & 0.721 & 0.101 & 0.935 & 0.00258 & 0.928767 & 9 & 8.477 \\
\hline & 0.486 & 0.00412 & 0.537 & 4.12E-03 & 0.925555 & 1.8 & 1.6664 \\
\hline Mean & 0.49975 & 0.031415 & 0.6385 & 0.00676 & 0.896605 & 4.4 & 3.9613 \\
\hline \multicolumn{8}{|c|}{ Oven dried ogi produced from White Maize } \\
\hline & 0.593 & 0.0136 & 0.536 & 0.0136 & 0.848717 & 2.39 & 2.15057 \\
\hline & 0.199 & 0.0477 & 0.8 & 0.0028 & 0.988634 & 3 & 2.29 \\
\hline & 0.408 & 0.00371 & 0.569 & $3.71 \mathrm{E}-03$ & 0.9608 & 7 & 6.379 \\
\hline & 0.458 & 0.00412 & 0.564 & 0.00412 & 0.9716 & 7 & 6.861 \\
\hline Mean & 0.4145 & 0.0172825 & 0.61725 & 0.006058 & 0.942438 & 8.3 & 5.7647 \\
\hline
\end{tabular}

Drying of ogi occurred predominantly in the falling rate period. This is indicative of the dominance of diffusion as physical mechanism governing moisture movements in the samples. This was consistent with the report by some researchers for greenbean (Rosello et al., 1997), okra (Gogus \& Maskan, 1999), red chilli (Gupta et al., 2002), Carrot (Prabhanjan et al.,1995) and eggplant (Ertekin \& Yaldiz, 2004; Falade et al., 2007). Generally, in this experiment, drying rates decreased with decreased moisture contents. Initially, there were higher drying rates when moisture contents were largest, after which, the drying rate decreased steadily with decreased moisture contents. This trend could be due to the removal of free moisture near the surface of the ogi paste at the early stages of drying. Moisture ratio decreased with increasing drying time. The solid content of ogi may be unconnected with the drying behavior (King, 1988; Lewicki, 2004; Mate et al., 1998; Falade et al., 2007). 
Table 6. Wang and Singh models constants and statistical parameters

\begin{tabular}{|c|c|c|c|c|c|c|}
\hline & $\mathrm{a}$ & B & $\mathrm{C}$ & $\mathrm{R}^{2}$ & $\operatorname{RSME}\left(\times 10^{-4}\right)$ & $\chi^{2}\left(\times 10^{-3}\right)$ \\
\hline \multicolumn{7}{|c|}{ Cabinet dried ogi produced from Yellow Maize } \\
\hline & -0.00263 & 0.00000454 & 0.963 & 0.961936 & 3 & 3.132 \\
\hline & -0.00371 & 0.0000142 & 0.962 & 0.957005 & 3 & 3.472 \\
\hline & -0.00339 & 0.0000105 & 0.94 & 0.915027 & 8 & 7.887 \\
\hline & -0.00272 & 0.000004 .47 & 0.971 & 0.976798 & 3 & 2.062 \\
\hline Mean & -0.00311 & $9.74667 \mathrm{E}-06$ & 0.959 & 0.952692 & 4.25 & 4.138 \\
\hline \multicolumn{7}{|c|}{ Oven dried ogi produced from yllowe Maize } \\
\hline & 0.00471 & 0.0000213 & 0.896 & 0.802636 & 23 & 22.885 \\
\hline & -0.00452 & -0.00191 & 0.93 & 0.901261 & 11 & 10.712 \\
\hline & -0.0053 & -0.0000212 & 0.91 & 0.897287 & 17 & 16.838 \\
\hline & -0.00249 & -0.00000283 & 0.999 & 0.972763 & 4 & 3.542 \\
\hline Mean & -0.0019 & -0.00047818 & 0.93375 & 0.893487 & 13.75 & 13.494 \\
\hline \multicolumn{7}{|c|}{ Cabinet dried ogi produced from White Maize } \\
\hline & -0.00967 & 0.00001 .89 & 0.89 & 0.933278 & 72 & 71.669 \\
\hline & -0.00246 & 0.000000515 & 0.91 & 0.83782 & 20 & 20.303 \\
\hline & -0.00302 & 0.00000049 & 0.97 & 0.906466 & 11 & 11.131 \\
\hline & -0.00158 & -0.0000153 & 0.98 & 0.969203 & 7 & 6.881 \\
\hline Mean & -0.00418 & $-4.765 \mathrm{E}-06$ & 0.9375 & 0.911692 & 275 & 27.496 \\
\hline \multicolumn{7}{|c|}{ Oven dreid ogi produced from White maize } \\
\hline & -0.00437 & 0.0000357 & 0.990 .9955 & 0.976467 & 33 & 0.033546 \\
\hline & -0.629 & 0.000026 & 0.967 & 0.972102 & 6 & 0.005601 \\
\hline & -0.00315 & 0.00000181 .3 & 0.97 & 0.961829 & 6 & 0.61123 \\
\hline & -0.00387 & 0.00000046 & 1.02 & 0.971916 & 6 & 0.005795 \\
\hline Mean & -0.1601 & 0.00002072 & 0.98566667 & 0.970579 & 12.75 & 0.164043 \\
\hline
\end{tabular}

\section{Conclusion}

The study has shown that drying pattern using the cabinet dryer and hot air oven decreased in moisture content with increased time of drying at the same temperature of $50{ }^{\circ} \mathrm{C}$. Drying of ogi may be achieved within the drying time employed in this research work.However, the quantity and the maxium capacity of the drying equipment used determine will be important to determing the drying time.

The Two term model showed a best model fit with Higher $\mathrm{R}^{2}$, lower $\chi^{2}$ and RMSE in this experiment. The cabinet dried ogi had Higher $\mathrm{R}^{2}$ and lower $\chi^{2}$ and $R M S E$ compared with values obtained for oven dried ogi produced from yellow and white maize. This is an indication of the possible effect of the rate and efficiency of dehydration method.

\section{References}

Akgun, N. A., \& Doymaz, I. (2005). Modelling of olive cake thin-layer drying process. Journal of Food Engineering, 68, 455-461. http://dx.doi.org/10.1016/j.jfoodeng.2004.06.023

Akingbala, J. O., Rooney, L. W., \& Faubion, J. M. (1981). Physical, Chemical and Sensory Evaluation of Ogi from Sorghum of different Kernel Characteristics. J. FoodSci., 46, 1532-1536. http://dx.doi.org/10.1111/j.1365-2621.1981.tb04214.x

Akpinar, E. K., Bicer, Y., \& Yildiz, C. (2003b). Thin layer drying of red pepper. Journal of Food Engineering, 59(1), 99-104. http://dx.doi.org/10.1016/S0260-8774(02)00425-9

Akpinar, E., Midilli, A., \& Bicer, Y. (2003a). Single layer drying behaviour of potato slices in a convective 
cyclone dryer and mathematical modelling. Energy Conversion and Management, 44(10), 1689-1705. http://dx.doi.org/10.1016/S0196-8904(02)00171-1

Akpinar, E. K., Bicer, Y., \& Cetinkaya, F. (2006). Modelling of thin layer drying of parsley leaves in a convective dryer and under open sun. Journal of Food Engineering, 75, 308-315. http://dx.doi.org/10.1016/j.jfoodeng.2005.04.018

Alvarez, C. A., Aguerre, R., Gomez, R., Vidales, S., Alzamora, S. M., \& Gerschenson, L. N. (1995). Air dehydration of strawberries: effects of blanching and osmotic pretreatments on the kinetics of moisture transport. Journal of Food Engineering, 25, 167-178. http://dx.doi.org/10.1016/0260-8774(94)00026-6

Alves-Filho, O. (2002). Combined innovative heat pump drying technologies and new cold extrusion techniques for production of instant foods. Drying Technology, 20(8), 1541-1557. http://dx.doi.org/10.1081/DRT-120014051

AOAC. (1990). Official Method of Analysis. Association of Official Analytical Chemists (No. 934.06), Washington, DC.

Bakri, H. H., \& Hobani, A. I. (2000). Thin layer drying of dates. J. Food Process Eng., 23, 177-189. http://dx.doi.org/10.1111/j.1745-4530.2000.tb00510.x

Banigo, E. O. I., de-Man, J. M., \& Duitschaever, C. L. (1974). Utilization of highlysine Corn for the Mnufacture of "Ogi" using a new improved processing system. Cereal Chem., 51, 101-111.

Belghit, A., Kouhila, M., \& Boutaleb, B. C. (2000). Experimental study of drying kinetics by forced convection of aromatic plants. Energy Conversion and Management, 44(12), 1303-1321. http://dx.doi.org/10.1016/S0196-8904(99)00162-4

Bolaji, O. T., Awonorin, S. O., Olalusi, A. P., Idowu, M. A., Henshaw, F. O., \& Adepoju, P. A. (2011). Effect of Storage Temperature on Some Ogi Properties Advance. Journal of Food Science and Technology, 3(2), 89-94.

Bruce, D. M. (1985). Exposed-layer barley drying, three models fitted to new data up to $150 \quad{ }^{\circ} \mathrm{C} . \quad$ Journal of Agricultural Engineering Research, 32, 337-347. http://dx.doi.org/10.1016/0021-8634(85)90098-8

Demirel, D., \& Turhan, M. (2003). Air-drying behavior of Dwarf Cavendish and Gros Michel banana slices. Journal of Food Engineering, 59, 1-11. http://dx.doi.org/10.1016/S0260-8774(02)00423-5

Doymaz, I. (2005). Drying behaviour of green beans. Journal of Food Engineering, 69, 161-165. http://dx.doi.org/10.1016/j.jfoodeng.2004.08.009

Doymaz, I. (2004). Effect of pre-treatments using potassium metabisulphide and alkaline ethyl oleate on the drying kinetics of apricots. Biosystems Engineering, 89, 281-287. http://dx.doi.org/10.1016/j.biosystemseng.2004.07.009

Doymaz, I. (2006). Drying kinetics of black grapes treated with differentsolutions. Journal of Food Engineering, 76, 212-217. http://dx.doi.org/10.1016/j.jfoodeng.2005.05.009

Doymaz, I., Gorel, O., \& Akgun, N. A. (2004). drying characteristics of the solid by-product of olive oil extraction. Biosystems Engineering, 88(2), 213-219. http://dx.doi.org/10.1016/j.biosystemseng.2004.03.003

Erenturk, S., \& Erenturk, K. (2007). Comparison of genetic algorithm and neural network approaches for the drying process of carrot. J. Food Eng., 78(3), 905-912. http://dx.doi.org/10.1016/j.jfoodeng.2005.11.031

Erenturk, S., Gulaboglu, M. S., \& Gultekin, S. (2004). The thin-layer drying characteristics of rosehip. Biosystems Engineering, 89(2), 159-166. http://dx.doi.org/10.1016/j.biosystemseng.2004.06.002

Ertekin, C., \& Yaldiz, O. (2004). Drying of eggplant and selection of a suitable thin layer drying model. Journal of Food Engineering, 63, 349-359. http://dx.doi.org/10.1016/j.jfoodeng.2003.08.007

Falade, K. O., Olurin, O. T., Ike, E. A., \& Aworh, O. C. (2007). Effect of pretreatment and temperature on air-drying of Dioscorea alata and Dioscorea rotundata slices. Journal of Food Engineering, 80, 1002-1010. http://dx.doi.org/10.1016/j.jfoodeng.2006.06.034

Gogus, F., \& Maskan, M. (1999). Water adsorption and drying characteristics of okra (Hisbiscus esculentus L.). Drying Technology, 17, 883-894. http://dx.doi.org/10.1080/07373939908917576

Gunhan, T., Demir, V., Hancioglu, E., \& Hepbasli, A. (2005). Mathematical modelling of drying of bay leaves. Energy Conversion and Management, 46, 1667-1679. http://dx.doi.org/10.1016/j.enconman.2004.10.001 
Gupta, P., Ahmed, J., Shivhare, U. S., \& Raghavan, G. S. V. (2002). Drying characteristics of red chilli. Drying Technology, 20, 1975-1987. http://dx.doi.org/10.1081/DRT-120015579

Hawlader, M. N. A., Perera, C. O., \& Tian, M. (2006). Properties of modified atmosphere heat pump dried foods. Journal of Food Engineering, 74(3), 392-401. http://dx.doi.org/10.1016/j.jfoodeng.2005.03.028

Henderson, S. M. (1974). Progress in developing the thin layer drying equation. Transactions of the ASAE, 17, 1167-1172. http://dx.doi.org/10.13031/2013.37052

Hernandez, J. A., Pavon, G., \& Garcia, M. A. (2000). Analytical solution of mass transfer equation considering shrinkage for modelling food drying kinetics. Journal of Food Engineering, 45, 1-10. http://dx.doi.org/10.1016/S0260-8774(00)00033-9

Hossain, M. A., \& Bala, B. K. (2002). Thin-layer drying characteristics for green chilli. Drying Technology, 20(2), 489-505. http://dx.doi.org/10.1081/DRT-120002553

Karathanos, V. T. (1999). Determination of water content of dried fruits by drying kinetics. Journal of Food Engineering, 39, 337-344. http://dx.doi.org/10.1016/S0260-8774(98)00132-0

Khazaei, J., Chegini, G. R., \& Bakhshiani, M. (2008). A novel alternative method for modeling the effects of air temperature and slice thickness on quality and drying kinetics of tomato slices: superposition technique. Drying Technology, 26, 759-775. http://dx.doi.org/10.1080/07373930802046427

King, C. J. (1988). Spray drying of food liquids and valatiles retention. In S. Bruin (Ed.), Preconcentration and drying of food materials (pp. 147-162). Amsterdam: Elsevier Science.

Kingsly, R. P., Goyal, R. K., Manikantan, M. R., \& Ilyas, S. M. (2007). Effects of pretreatments and drying air temperature on drying behavior of peach slice. International Journal of Food Science and Technology, 42, 65-69. http://dx.doi.org/10.1111/j.1365-2621.2006.01210.x

Lewicki, P. P. (2004). Water as the determinant of food engineering properties. A review Journal of Food Engineering, 61, 483-495. http://dx.doi.org/10.1016/S0260-8774(03)00219-X

Lima, A. G. B., Queiroz, M. R., \& Nebra, S. A. (2002). Simultaneous moisture transport and shrinkage during drying of solids with ellipsoidal configuration. Chemical Engineering Journal, $86, \quad 85-93$. http://dx.doi.org/10.1016/S1385-8947(01)00276-5

Madamba, P. S., Driscoll, R. H., \& Buckle, K. A. (1996). The thin layer drying characteristics of garlic slices. Journal of Food Engineering, 29, 75-97. http://dx.doi.org/10.1016/0260-8774(95)00062-3

Maskan, A., Kaya, S., \& Maskan, M. (2002). Hot airand sun drying of grape leather. Journal of Food Engineering, 54, 81-88. http://dx.doi.org/10.1016/S0260-8774(01)00188-1

Maskan, M. (2001). Drying, shrinkage and rehydration characteristics of kiwifruits during hot air and microwave drying. Journal of Food Engineering, 48(2), 177-182. http://dx.doi.org/10.1016/S0260-8774(00)00155-2

Mate, J. I., Quartert, C., Meerdink, G., \& van't Riet, K. (1998). Effect of balancing the structural quality of dried potato slices. Journal of Agriculture and Food Chemistry, 46(2), 676-681. http://dx.doi.org/10.1021/j9970671p

Menges, H. O., \& Ertekin, C. (2006). Modeling of air drying of Hacihaliloglu-type apricots. Journal of the Science of Food and Agriculture, 86, 279-291. http://dx.doi.org/10.1002/jsfa.2340

Midilli, A. (2001). Determination of pistachio drying behavior and conditions in a solar drying system. International Journal of Energy Research, 25, 715-725. http://dx.doi.org/10.1002/er.715

Midilli, A., \& Kucuk, H. (2003). Mathematical modelling of thin layer drying of pistachio by using solar energy. Energy Conversion and Management, 44, 1111-1122. http://dx.doi.org/10.1016/S0196-8904(02)00099-7

Moraga, G., Martinez-Navarrete, N., \& Chiralt, A. (2004). Water sorption isotherms and glass transition in strawberries: influence of pretreatment. Journal of Food Engineering, 62, 315-321. http://dx.doi.org/10.1016/S0260-8774(03)00245-0

Ojendiran, J. O., \& Raji, A. O. (2010). Thin layer drying of millet and effect of temperature on dryingcharacteristics. Int. Food Res. J., 17, 1095-1106.

Ozdemir, M., \& Devres, Y. O. (1999). The thin layerdr ying characteristic of hazelnuts during roasting. Journal of Food Engineering, 42, 225-233. http://dx.doi.org/10.1016/S0260-8774(99)00126-0

Page, C. (1949). Factors influencing the maximum rates of air drying shelled corn in thin layers. Unpublished 
MS Thesis,Purdue University, Lafayette, IN.

Pahlavanzadeh, H., Basiri, A., \& Zarrabi, M. (2001). Determination of parameters and pretreatment solution for grape drying. Drying Technology, 19, 217-226. http://dx.doi.org/10.1081/DRT-100001363

Parry, J. L. (1985). Mathematical modelling and computer simulation of heat and mass transfer in agricultural grain drying. Journal of Agricultural Engineering Research, 54, 339-352.

Prabhanjan, D. G., Ramaswamy, H. S., \& Raghavan, G. S. V. (1995). Microwave-assisted convective air drying of thin layer carrots. Journal of Food Engineering, 25, 283-293. http://dx.doi.org/10.1016/0260-8774(94)00031-4

Rangroo, S., \& Rao, D. G. (1992). Drying of Toria seeds (Brassica Campestris): Part 2, Drying Conditions. $J$. Food Eng., 17, 59-68. http://dx.doi.org/10.1016/0260-8774(92)90065-E

Rosello, C., Simal, S., SanJuan, N., \& Mulet, A. (1997). Nonosptropicmass transfer model for green bean drying. Journal of Agricultural andFood Chemistry, 45, 337-342. http://dx.doi.org/10.1021/jf960534c

Sacilik, K., \& Unal, G. (2005). Dehydration Characteristics of Kastamonu Garlic Slices. Biosystems Engineering 92(2), 207-215. http://dx.doi.org/10.1016/j.biosystemseng.2005.06.006

Sahin, A. Z., \& Dincer, I. (2005). Prediction of drying times for irregular shaped multi-dimensional moist solids. Journal of Food Engineering, 71(1), 119-126. http://dx.doi.org/10.1016/j.jfoodeng.2004.10.024

Saravacos, G. D., Karathanos, V. T., Marousis, S. N., Drouzas, A. E., \& Maroulis, Z. B. (1990). Effect of gelatinization on the heat and mass transport properties of starch materials. In W. E. L. Spiess \& H. Schubert (Eds.), Engineering and Food (Vol. 1, pp. 390-398).

Sarsavadia, P. N., Sawhney, R. L., Pangavhane, D. R., \& Singh, S. P. (1999). Drying behavior of brined onion slices. Journal of Food Engineering, 40, 219-226. http://dx.doi.org/10.1016/S0260-8774(99)00058-8

Sarsilmaz, C., Yildiz, C., \& Pehlivan, D. (2000). Drying of apricots in a rotary column cylindrical dryer (RCCD) supported with solar energy. Renewable Energy, 21, 117-127. http://dx.doi.org/10.1016/S0960-1481(00)00077-X

Shi, Q. -L., Chang-Hu X., Zhao, Ya, Zhao-Jie, L., \& Xiang-Y. W. (2008). Drying characteristics of horse mackerel (Trachurus japonicus) dried in a heat pump dehumidifier. Journal of Food Engineering, 84, 12-20. http://dx.doi.org/10.1016/j.jfoodeng.2007.04.012

Syamali, A. K., Jayaweera, H. H. E., \& Ariyaratne, T. R. (2009). Thin layer drying of some Srilankan paddy varieties under low humid conditions. Proceedings of Technical Sessions, Institute of Physics, Srilanka, 25, $36-44$.

Thakor, N. J. (1999). Mass and dimensional changes of single canola kernels during drying. Journal of Food Engineering, 40, 153-160. http://dx.doi.org/10.1016/S0260-8774(99)00042-4

Togrul, I. T., \& Pehlivan, D. (2003). Modeling of drying kinetics of single apricot. Journal of Food Engineering, 58(1), 23-32. http://dx.doi.org/10.1016/S0260-8774(02)00329-1

Toyosi, Y. T., \& Adeladun, A. (2010). Air drying characteristics of chili pepper. Int. J. Food Eng., 6(1), 1-15.

Wang, C. Y., \& Singh, R. P. (1978). Use of variable equilibrium moisture content in modeling rice drying. Transactions of ASAE Paper 78-6505

Yaldiz, O., Ertekin, C., \& Uzun, H. I. (2001). Mathematical modeling of thin layer solar drying of Sultana grapes. Energy-An International Journal, 26, 457-465. http://dx.doi.org/10.1016/S0360-5442(01)00018-4

Yaldiz, O., \& Ertekin, C. (2001). Thin layer solar drying of some vegetables. Drying Technology, 19, 583-596. http://dx.doi.org/10.1081/DRT-100103936

\section{Copyrights}

Copyright for this article is retained by the author(s), with first publication rights granted to the journal.

This is an open-access article distributed under the terms and conditions of the Creative Commons Attribution license (http://creativecommons.org/licenses/by/3.0/). 